\title{
Association between Annual River Flood Pulse and Paediatric Hospital Admissions in the Mekong Delta Area
}

Dung Phung ${ }^{1}$, Cunrui Huang ${ }^{1}$, Shannon Rutherford ${ }^{1}$, Cordia Chu ${ }^{1}$

Xiaoming Wang $^{2}$, Minh Nguyen ${ }^{2}$

${ }^{1}$ Centre for Environment and Population Health (CEPH), Griffith University, Queensland, Australia

${ }^{2}$ Commonwealth Scientific and Industrial Research Organisation (CSIRO), Australia

\section{Corresponding Author:}

Dung Phung

Phone: $\quad+61(07) 37355078$

Fax: $\quad+61(07) 37355318$

Email: $\quad$ d.phung@griffith.edu.au

Address: $\quad$ Centre for Environment and Population Health

Nathan campus, Griffith University

179 Kessels Road, Nathan

Brisbane, Queensland 4111, Australia 


\section{Abstract}

The Mekong Delta is the most vulnerable region to extreme climate and hydrological conditions however the association between these conditions and children's health has been little studied. We examine the association between annual river flood pulse and paediatric hospital admissions in a Vietnam Mekong Delta city.

Daily paediatric hospital admissions (PHA) were collected from the City Paediatric Hospital, and daily river water level (RWL) and meteorological data were retrieved from the Southern Regional Hydro-Meteorological Centre from 2008 to 2011. We evaluated the association between annual river flood pulse $\left(>=90^{\text {th }}\right.$ percentile of RWL) and PHA using the Poisson distributed lag model, controlling for temperature, relative humidity, day of week, seasonal and long-term trends. The seasonal pattern of PHA was examined using harmonic and polynomial regression models.

The cumulative risk ratios estimated for a 15-day period following an extreme RWL was 1.26 (95\%CI, 1.2-1.38) for all age groups, 1.27 (95\%CI, 1.23-1.30) for under five-years and 1.15 (95\%CI, 1.07-1.20) for school-aged children, 1.24 (95\%CI, 1.21-1.27) for allcauses, 1.18 (95\%CI, 1.12-1.21) for communicable infection, 1.66 (95\%CI, 1.57-1.74) for respiratory infection and 1.06 (95\%CI, 1.01-1.1) for other diseases. The peak PHA risk is in the September-October period corresponding to the highest RWL, and the PHA-RWL association was modified by temperature.

An increase in PHA is significantly associated with annual river flood, and the pattern of PHA is seasonally correspondent to the RWL. These findings combined with projected changes in climate conditions suggest important implications of climate change for human health in the Mekong Delta region. 


\section{Introduction}

The flooding events, which have become more frequent in recent years and have become a great public health concern (Prudhomme et al. (2003), were believed to have a significant impact on children in both high- and low-income areas (Alderman et al. 2012; Yeo and Blong 2010). The potential direct and indirect adverse health effects of floods included drowning and acute trauma (Jonkman et al. 2009;Pradhan et al. 2007;Yeo and Blong 2010), injuries (Ahern et al. 2005;Abaya et al. 2009;Diaz 2004;Sullivent et al. 2006), toxic exposure (Euripidou and Murray 2004;Fox et al. 2009), water- and vector-borne diseases (World Health Organization 2011) such as diarrhoea (Abaya et al. 2009;Schwartz et al. 2006;Vollaard et al. 2004), respiratory and skin infections (Diaz 2004;Caroll et al. 2010; Reacher et al. 2004), dengue fever and malaria (World Health Organization 2011;Sidley 2008;Abaya et al. 2009), and non-communicable diseases such as malnutrition and mental health disorders (Berry et al. 2008;Nino and Lundberg 2005; Goudet et al. 2011).

Besides the effects of climate change, urbanization, which has rapidly shifted of rural to urban land use in developing countries recently, also leads to increased risk of flooding and its association with human health effects. Urbanization significantly causes rigorous changes of land cover, resulting elevated risk of flooding as more population and property are being placed in the newly developed lands (Dewan and Yamaguchi 2008). In addition, urbanization results to the reduction of surface roughness, shortens the runoff travel time, and increase peak discharges which makes flood hazard susceptibility distinctly higher in urbanized areas (Nirupama and Simonovic 2007). Nevertheless, cities in developing areas in Asia are not capable enough to deal with increased flood-related health problems because of their high rates of population and poverty as well as their poor adaptive capacity (Tol 2008;Adger 2006;Dewan 2013). Moreover, health consequences of floods depend greatly on geographic and socio-economic factors as well as the characteristics of the population affected (Ahern et 
al. 2005;Du et al. 2010). Therefore, understanding the pattern of flood-health effect relationship should be addressed ideally in the specific location and for the specific vulnerable groups in terms of public health preparedness and prevention (Hunter Health 2003).

The Mekong River Delta (MRD) is considered as the most vulnerable region to extreme climate and hydrological events in Southeast Asia (Yusuf and Francisco 2009). The study (Vastila et al. 2010) indicated that the projected flood duration in the MRD highly likely increase in all the simulated scenarios. The flood start and end dates are projected to occur earlier and later respectively. Besides the flood pulse, which occurs annually, other studies (Delgado et al. 2010;Eastham et al. 2008) also predicted an increasing likelihood of extreme floods. It was estimated that $74 \%$ of all victims of the extreme flood events in MDR were children under six years old (CFSC [Committee for Flood and Storm Control 2004). Nevertheless, the previous investigation only focused on surveys fatality and injury but not on hospitalized morbidity. Moreover, besides the extreme flood events due to intense or prolonged rainfall and tidal extremes (Birkmann et al. 2010), the effects of the usual river flood pulse have been neglected in the previous studies.

The objectives of this study were (i) to investigate the short-term association between paediatric hospital admission and annual river flood pulse which is represented by the high river water level, and (ii) to examine the seasonal pattern of paediatric hospital admissions in Can Tho city, the Vietnam Mekong Delta area.

\section{Materials and Methods}

\subsection{Study location}

The study was conducted in Can Tho city, a city in Mekong Delta in Vietnam (Figure 1). Can Tho is the fourth most populous city in Vietnam with a total area of $1,411.49 \mathrm{~km}^{2}$ and 
a population of 1,188,390 people, and a population density of 842 people $/ \mathrm{km}^{2}$ (Huyen 2012). Located in the heart of the Mekong Delta, Can Tho residential life is strongly affected by the meteorological and hydrological factors. The annual river flood pulses usually occur from May to November due to increased flows from upstream, tidal surges and intense local rainfall in Can Tho. The extent and depth of flooding varies depending on meteorological and hydrological factors and infrastructure construction, with an estimated area of 9,700ha36,000ha under 1 metre of water (Neumann et al. 2013). These higher water levels and runoff increase the mobilisation of pathogens, pesticides, dissolved and absorbed pollutants and heavy mental, potentially resulting in negative impacts on residential health in Mekong Delta (Bates et al. 2008).

\subsection{Data collection}

\subsubsection{Hospital admissions data}

Daily paediatric hospital admissions (PHA) data from $1^{\text {st }}$ January 2008 to $30^{\text {th }}$ December 2011 were collected from the Can Tho City Paediatric Hospital which is the sole public hospital for children in Can Tho city, and hence represents a strong majority of paediatric patients in the research location. The data comprise: date of birth, date of admission, diagnosis as per International Classification of Disease (ICD10), and date of hospital discharge. These data were cleaned to exclude patients who are not Can Tho residents and to collapse data by date of admission, age (<=5 and 5-15 year-olds), disease groups comprising: communicable infectious diseases [A00-A99, excluding infections with a predominantly sexual mode of transmission; B00-B99, excluding human immunodeficiency virus (HIV)], respiratory infection (J00-J22), and the rest including all other diseases with the exclusion of malignant neoplasms and other neoplasms (C00-97, D00-49) and external causes of morbidity and mortality (V01-Y98). The data collection was permitted by Vietnam Health Environment Management Agency (VHEMA), Ministry of Health in Vietnam that is 
the leading agency responsible for climate change and health among health sectors in Vietnam, and the permission and supports were also provided by Can Tho Health Department, the leading health management agency in the local area.

\subsubsection{Meteorological and river water level data}

Daily meteorological and river level data, monitored at the Can Tho HydroMeteorological Station and available from the Southern Regional Hydro-Meteorological Centre, were also collected for the period January 2008- December 2011. The parameters comprises of daily average temperature $\left({ }^{\circ} \mathrm{C}\right)$, daily relative humidity $(\%)$, and the maximum river water level (RWL) in the Tien River, a section of the Mekong Delta River which runs through Can Tho city. As classified by Can Tho Committee for Flood and Storm Control (CCFSC), the warning levels for the river flood correspond to the specific river water level, of which flood warning level 1 is $170 \mathrm{~cm}$, level 2 is $180 \mathrm{~cm}$, and level 3 is $190 \mathrm{~cm}$. These warning levels were used to urge local authorities and inhabitants to prepare for flood risk reduction and mitigation.

\subsection{Data analysis}

Initially, a restricted cubic spline function was used to control for seasonal and longterm trends of dependent variable (PHA) and to take account for potential non-linear effects of exposure variables (RWL, and meteorological parameters). We first estimated the spline term based on the entire time series using all days and single unadjusted Poisson regression models, and then incorporates the spline estimates as an offset in the full models. The predicted values of the outcome and exposure variables were then calculated from the fitted spline function models. The restricted cubic spline was applied because splines are possibly more flexible than fractional polynomial function, so it may be suitable for modelling complex functions (Royston and Sauerbrei 2007). In addition, it is an easy way of including explanatory variables in a smooth non-linear way in a wide variety of models. The number 
of knots was set at 7 in this analysis, since 7 per year has been considered as a balance between providing adequate control for seasonality and other confounding by trend in time, while leaving sufficient information from which to estimate exposure effects (Dominici et al. 2000).

We hypothesized that the highest level of RWL, representing an occurrence of annual river flood pulse, would be associated with in increased risk of paediatric hospital admission, so the $90^{\text {th }}$ percentile was chosen as the cut-off point $\left(<90^{\text {th }}\right.$ percentile: reference category, and $>=90^{\text {th }}$ percentile: examined category). This hypothesis is based on previous studies which indicated that a majority of waterborne disease outbreaks were preceded by extreme meteorological and hydrological parameters (Harper et al. 2011;Curriero et al. 2001;Rose et al. 2000). In the following step, the Poisson distributed lag model (Equation 1) was used to examine the lag effects between exposure to increase of RWL and subsequent occurrence of PHA, and the time lags for this variability were taken at a 15-day lag.

$$
\operatorname{Ln}[E(P H A)]=\beta_{0}+\beta_{1} R W L_{t-q}+\beta_{2} A T_{t}+\beta_{3} R H_{t}+\beta_{4} D O W_{t}+s(\text { time }) \quad \text { Equation } 1
$$

where $P H A$ is the count of daily paediatric hospital admissions, $R W L$ is the daily river water level, $t$ represents the day of hospitalization, $q$ denotes single-day lags 1-15 days before the day of hospital admission ( $q=1,2, \ldots, 15), A T$ is daily average temperature, $R H$ is daily relative humidity, $D O W$ is day of week, and $s$ (time) is a penalized spline using calendar time with smoothing parameters at 7 knots.

In order to examine the association between extreme RWL and PHA, the Poisson models (Equation 2) were fit with daily counts of PHA as the dependent variable and categorical daily RWL as the independent variable, adjusted for potential confounding factors, including AT, RH, and DOW. The previous studies illustrated that temperature, humidity, or a combination of these meteorological factors are associated with the replication, persistence, and transmission of pathogens in the environment (Checkly et al. 2000;Fleury et 
al. 2006;Namouva et al. 2007; Singh et al. 2001). All models included AT and RH as continuous variables. The cumulative effect over a 15-day period following an extreme RWL event was computed from the model using a quadratic distributed lag function in order to reduce collinearity resulting from correlated RWL on days that are close lags. This function allows us to model the cumulative effects of RWL over the entire lag period and simultaneously compute the nonlinear and delayed effects (Bush et al. 2014).

$\operatorname{Ln}[E(P H A)]=\beta_{0}+\sum_{q=1}^{15} \delta_{q} R W L_{t-q}+\beta_{2} A T_{t}+\beta_{3} R H_{t}+\beta_{4} D O W_{t}+s($ time $)$ Equation 2 where $\delta_{q}$ is the effect of extreme RWL ( $>=90^{\text {th }}$ percentile) q days before the day of hospitalization. The cumulative summary of risk ratio estimates corresponding to extreme RWL is given as $\sum_{q}^{15} \delta_{q}$.

We conducted 2 sensitivity analyses. First, the association between PHA and RWL was conducted by specifying exposure variable, RWL in a different way. A categorized RWL using an ordinal scales (50-80, 80-110, 110-140, 140-170, 170-200, >200 cm) was examined. This scale was used to examine the linear relationship between RWL and risk of PHA after adjusting for meteorological factors and day of week. We hypothesized that age and disease group could be modifying factors for the RWL-PHA relationship, so the sensitivity analyses were also conducted for separate groups queried by age ( $<=5$ and 5-15 year-olds) and diseases (communicable infection, respiratory infection, and others). Second, we performed a sensitivity analysis to test the impact of number of knots $(7,6,5$, and 4$)$ on the regression results to determine the optimal number of knots to control for long-term and seasonal trend in the models.

Finally, the seasonal pattern of PHA was examined. Consultation with local hydrologists and analysis in the seasonal pattern of RWL confirmed that the annual river flood pulse usually occurs from August to October. We developed a harmonic regression model (Equation 3) from January to June, one month before the peak period of RWL because 
the previous study found that water contamination and illness could be elevated a month prior to the flood event due to the run off as a result of heavy rainfall (CCDR 2000). We then used the developed regression model to predict expected admissions for the period of July December. The risk ratios were calculated by comparing observed and expected admissions over time. The seasonal pattern of PHA risk ratio was examined using a fitted polynomial regression model, and this was evaluated by the levels of temperature and humidity (high, >mean; normal, <= mean). All data analyses were conducted using Stata version 11.0 (Stata Corporation, College Station, TX, USA).

$$
\operatorname{Ln}[E(P H A)]=\beta_{0}+\beta_{1} \sin (2 \pi \omega t)+\beta_{2} \cos (2 \pi \omega t)+\varepsilon_{t}
$$

Equation 3

where PHA is the count of paediatric hospital admissions, $t$ is time in days, $\omega$ is frequency $(\omega=1 / 30.25), \varepsilon$ is the error term.

\section{Results}

\subsection{Descriptive analysis}

Daily river water level (RWL) during the study period ranged from 40 to $215 \mathrm{~cm}$ with a daily mean of $125 \mathrm{~cm}$ (95\%CI, 123-126). RWL at $166 \mathrm{~cm}$ (the $90^{\text {th }}$ percentile), which is approximate to the $1^{\text {st }}$ flood warning level $(170 \mathrm{~cm})$, was used as the cut-off point for extreme RWL in this analysis. The total number of annual river flood pulses with RWL above 166 cm was 149 (Table 1). The year 2011 had 10 to 21 more days of extreme RWL than the other years. The seasonal RWL was significantly higher in the wet season, which ranged from 65 to $215 \mathrm{~cm}$, than in the dry season, which ranged from 40 to $184 \mathrm{~cm}$. The number of days with extreme RWL in the wet season was 8 times as many as that in the dry season (132 versus 17 days). The histogram, Q-Q plots, and Shapiro-Wilk test $(\mathrm{p}<0.01)$ showed a slightly left skewed distribution of RWL (mean, $125 \mathrm{~cm}$; median, $122 \mathrm{~cm}$ ); out of the total of 1458 days, 653 days (43\%) had a RWL greater than the mean. During the study period, daily AT ranged from 21.5 to $31.4^{\circ} \mathrm{C}$ with a daily mean of $27.2^{\circ} \mathrm{C}(95 \% \mathrm{CI}, 27.1-27.3)$. The temperature was 
relatively consistent at around $27^{\circ} \mathrm{C}$ across the years and seasons (Table 1). Distributional tests showed a normal distribution of the daily $\mathrm{AH}$ (mean, 27.2; median, $27.3^{\circ} \mathrm{C}$ ). $\mathrm{RH}$ ranged from $65-97 \%$ with the mean of $82 \%$ (81.7-82.3) and a normal distribution (mean, 82; median, 82). This parameter was a bit higher in the wet season (mean, 84.5\%) than in the dry season (mean, 82\%). Across the years, the RH seems to have decreased from 2008 to 2011.

The total number of PHA from all causes recorded during 2008-2011 was 44,542, of which $77.5 \%$ were for under-5 year-olds at the date of admission, and $64 \%$ were infectious diseases (Table 2). The number of PHA in the wet season was nearly 3 times as high as that in the dry season for all age and disease groups. The PHA caused by infectious diseases seems to have increased in 2009-2010 with children less than 5 year-olds whereas the admissions caused by other diseases were more numerous in 2011. The seasonality of PHA started increasing from Week 27 (July) and peaked at Week 40-44 (October), then went down from Week 50 (early December) each year (Figure 1). The increase of PHA appears to correspond with the increase on RWL and RH at the same month lag while there seems to be a delayed response with a several month lag for admissions and temperature (Figure 3). However, this study only examined the short-term association within 15 day lags only. 3.2 Association between paediatric hospital admission and river water level

The results of the multivariate Poisson distributed lag model using a quadratic distributed lag function, extreme RWL was significantly associated with increased PHA with a cumulative risk ratio of 1.26 (95\%CI, 1.2-1.38) after a 15-day lag following an extreme RWL event (Table 3). Among the young children ( $<=5$ year-olds), the risk ratio of PHA was 1.27 (95\%CI, 1.23-1.30) for cumulative 15-day lag following an extreme RWL compared with a 15-day period with moderate RWL. Among the school-age children (5-15 year-old), the risk ratio was also significantly positive but on a smaller scale: the risk ratio was 1.15 (95\%CI, 1.07-1.20). In terms of disease groups, the risk ratio of PHA was 1.24 (95\%CI, 1.21- 
1.27) for all causes, 1.18 (95\%CI, 1.13-1.22) for communicable infectious diseases, 1.66 (95\%CI, 1.57-1.74) for respiratory infectious diseases, and 1.06 (95\%CI, 1.01-1.1) for other diseases after 15-day period following an extreme RWL.

The sensitivity analysis, which categorized RWL in different ways as described in Section 2.3, demonstrated a linear-trend relationship between PHA and RWL. Compared with the RWL of $50-80 \mathrm{~cm}$, at the level of $80-110 \mathrm{~cm}$ the risk ratio of PHA increased by $2 \%$ (RR, 1.02, 95\%CI, 0.96-1.08), and at a RWL of 110-140cm it rose by 5\% (RR, 1.05, 95\%CI, 0.98-1.11), but these increases were not statistically significant ( $\mathrm{p}>0.1)$. In fact, the risk ratio of PHA statistically increased by14\% (RR, 1.14, 95\%CI, 1.07-1.20) when RWL was at the level of 140-170cm, by $20 \%$ (RR, 1.2, 95\%CI, 1.12-1.28) when RWL was at the level of 170$200 \mathrm{~cm}$, and by $28 \%$ when RWL was more than $200 \mathrm{~cm}$. The cumulative risk ratio increased by $16 \%(\mathrm{RR}, 1.16,95 \% \mathrm{CI}, 1.14-1.17)$ following a 15-day period of $30 \mathrm{~cm}$ increase in RWL above the level of $80-110 \mathrm{~cm}$. The sensitivity analysis, which used lower number of knots in the regression models, revealed that change in number of knots per year for the time trend did not substantially affect the estimated effects of RLW on PHA, indicating that our findings were relatively robust in this regards. For example, the risk ratio of PHA statistically increased by $22 \%$ (RR, 1.22, 95\%CI, 1.18-1.24) for all causes, and that increased by 25\% (RR, 1.25, 95\%CI, 1.20-1.27) for less than 5 year-old if the number of knots was 5 per year. 3.3 Seasonal pattern of paediatric hospital admissions

The risk ratios of PHA, which were computed using the harmonic regression model, illustrate that the risk of PHA among children in Can Tho city starts increasing in May, with a statistically the significant increase found from July (Figure 4). The peak in risk ratio is within September-October which corresponds with the highest RWL in the year, and the risk ratio of PHA starts declining from November-December. The seasonal pattern of PHA was significantly influenced by the variation in daily average temperature during and after the 
annual flood season. Figure 4 shows that the peak of risk ratio was about $10 \%$ higher in the days with temperature $>27^{\circ} \mathrm{C}$ (mean level) compared with the risk ratio in the days with temperature $<=27^{\circ} \mathrm{C}$, and the declining stage of risk ratio for the hot days was much slower than that for the normal temperature days. However the seasonal pattern of PHA was not influenced by the change in humidity, since the peak and declining stages of risk ratio showed no difference between the high humid days (>82\%) and moderate humid days $(<=82 \%)$ (Figure 4).

\section{Discussion}

This is the first study of the association between annual river flood pulse, which was represented by river water level, and hospital admissions among children in the Mekong Delta area. The study results indicate a significantly positive association between PHA and extreme RWL ( $>=90^{\text {th }}$ percentile) over a 15-day lag. The threshold of sensitivity for RWL associated with increase of PHA is found at the level of $170 \mathrm{~cm}$. Young children (under-five year-olds) and respiratory infection are more sensitive to extreme RWL than school-age (5-15 year-olds) and other diseases.

The plausible explanation for the flood-disease association is the presence of contaminated water due to flood and related factors. Floods interacted with climate variability undermine clean water supplies and cause significant risk of water-related diseases among children, especially in less developed areas. For instance, flooding causes expansion of river channel, increase in water velocity, overland flow, and occurrence of shallow subsurface flow, resulting in high water turbidity and potentially transporting pathogens, so that drinking water sources are contaminated (Harper et al. 2011). Moreover, high turbidity levels can protect pathogens from natural disinfection, as well as hinder other disinfection techniques (Aramini et al. 2000). Therefore, the risk of exposure to waterborne pathogens is increased as 
a result of run-off and increased turbidity (Curriero et al. 2001;Schuster et al. 2005; Thomas et al. 2006). In addition, children must consume more water per body mass than adults while their immune systems are less developed than those of adults, resulting in less effective in fighting pathogens (Bunyavanich et al. 2003). The low-income inhabitants which live close to water bodies may have elevated risk of infection during the flooding season, since they frequently use contaminated surface water for cooking, bathing etc. (Dewan 2013;Corner et al. 2013).

The finding of this current study was consistent with previous studies of the association between climate factors which cause elevation of river water level and human health adverse effects. There were a few studies (Kien et al. 2010;Few et al. 2009;Kelly-Hope et al. 2008) investigated the relationship between climate-related conditions and water-borne diseases in Vietnam Mekong Delta, and these studies indicated that enteric infections among general populations were associated with annual floods. For example, the study by Kien et al (2005) typhoid fever is endemic for the Mekong River Delta and rates correspond to increase in annual floods, and that was more serious when the floods interacted with high temperature. Another study by Kelly-Hope et al (2008) found that significant increase of shigellosis/dysentery, cholera, and typhoid associated with high precipitation periods. However these studies did not evaluate the effects of annual floods on children health impacts separately.

The findings are also relevant to that from previous studies which have been conducted in somewhere else worldwide. Daily paediatric hospital admissions for diarrhoea in Peru increased 200\% over baseline after the flooding and high temperature triggered by 1997-98 El Nino (Checkly et al. 2000). A study based in Chennai India indicated that extreme precipitation was associated with 2.72 times increase in the number of gastrointestinal-related illness among young children (<=5 year) (Bush et al. 2014). The 
studies also found that an interquartile range in drinking-water turbidity likely caused by extreme precipitation caused an elevated risk of hospital admission among children 0-15 year-olds (Schwartz et al. 1997); a 10-cm river-level rise above threshold was associated with a 5.5\% increase in cases of rotavirus diarrhoea (Hashizume et al. 2007b), and a $10 \mathrm{~mm}$ increase above threshold of $52 \mathrm{~mm}$ of average rainfall was associated with a $5.1 \%$ increase in non-cholera diarrhoea cases (Hashizume et al. 2007a). Among water-borne infections, the typhoid incidence associated with river water levels was highest among young children (0-4 years) and elderly people (60+), and a statistically significant inverse association was found between typhoid incidence and distance to major water bodies (Dewan et al. 2013;Corner et al. 2013). The vector-borne disease such as dengue fever was also found elevated with high river level at shorter lags with the highest at a lag of six weeks (Hashizume et al. 2012). However the positive effect of lower level was also found at the longer lags and this study did not analysed age-specific effects for children separately. The study by Milojevic et al (2012) found the moderate increase in risk of acute respiratory infection among 0-15 year-old children during the six months after the flood but no positive relationship found during the flood. That finding is different from the finding from this study that the increased risk of respiratory infections among young children within 0-15 day of flooding events.

The seasonal analysis revealed a significant association between the annual river flood pulse and PHA among children during the wet season: the seasonal peak of PHA corresponded to the annual peak of RWL (September-October). Although this study did not evaluate the association between extreme low RWL and PHA because there were very few days (2 observations) with RWL lower than $50 \mathrm{~cm}$ during the study period, its finding is consistent with the previous studies which indicated that admission rates are elevated during both the high and low water level periods and related factors (Hashizume et al. 2007a;Nichols et al. 2009). It is noteworthy that the magnitude and time-length of increase in PHA during- 
and post-flood are found to be modified by temperature, in which the bigger magnitude and longer period of increase in hospital admissions during high temperature were found in this study. The plausible mechanism for the modifying effects of temperature may relate to the obvious link between waterborne disease and the temperature-induced blooms of various planktonic species that are directly or indirectly hazardous to children's health. For example, high temperature can lead to blooms of Cyanobacteriae (Blue-green algae), Dinoflagellates, Pfiesteria piscicida which can cause dermatitis, respiratory problems, neurotoxic reactions, diarrhoea, or eye irritation (Hunter 1998;Hungerford 2001; Morris 1999). Moreover, it has also been suggested that higher water temperature will cause prolonged survival of pathogens in the environment (Chief Medical Officer 2001). The previous work also indicates that the effects of temperature on waterborne diseases such as diarrhoea is also related to the socioeconomic status of a vulnerable population, so that people with lower educational attainment, living in households with non-concrete roof, and users of unsanitary toilets are more vulnerable to waterborne disease during high temperature periods (Hashizume et al. 2007a).

An understanding of the association between the annual flood pulse represented by RWL and PHA will have important implications for preventive medicine, hospital preparedness, and for water-resource professionals in the Mekong Delta region where a lowincome and weak environmental hygiene conditions, where there is a high burden of waterborne diseases. Besides the extreme flood events, which are unpredictable, an annual river flood pulse can be considered as a predictable health hazard that continues to lead to health issues for vulnerable residents along the river delta, so health prevention and preparedness corresponding to the usual variability of RWL should be considered as important as unpredictable extreme flood events. For preventive medicine, appropriate water resource management, sanitation, access to clean water supplies, and piped sewage connections are necessary to reduce the risk of hospital admission for waterborne diseases. 
The study also suggests that raising the awareness of residents about the link between a river flood pulse and related diseases, and developing a model for an early-warning system using weather prediction could be considered as a part of the solution (Bush et al. 2014). Similarly, preparedness such as enhanced drug stock and hospital bed availability should be enhanced if the seasonal pattern of risk of hospital admissions is considered to be important data for the planning process among the local hospitals. This study may be the good start for this purpose in Mekong Delta region, since it uses a cost-effective design, time-series, to examine association between meteorological/hydrological data and seasonal pattern of risk of hospital admission. The data collected for the study uses existing data from highly reliable sources: meteorological centres and hospital record systems.

The primary limitation of this current study is that PHA remains under-reported because we did not consider minor cases that were admitted and treated in the lower-level hospitals in Can Tho such as district hospitals and commune health clinics. Therefore, the PHA in the study is more representative for moderate and severe cases. However, Can Tho paediatric hospital is the sole paediatric hospital in Can Tho city, so the hospital admissions are still highly representative of children's admissions in the research location. In addition, moderate and severe cases of hospital admissions are more precisely classified for ICD than the minor cases in the lower-level hospitals because a more reliable and consistent health record system is found in the higher level hospitals in Vietnam. The second limitation found in this study is that the potential influence of redistribution of districts conducted in 2008 in Can Tho, in which more districts were split from the original districts, was not evaluated. This redistribution might change land use, urban and rural population, development of infrastructure, or water and sanitation systems, which potentially have effects on the risk of disease among residents. Any future study should take these factors into account for data collection and analysis. 


\section{Conclusions}

This current study revealed a positive association between annual river flood pulse, which is represented by the threshold of river water level at $170 \mathrm{~cm}$, and the increase of paediatric hospital admissions in the typical Mekong Delta area, Can Tho city. The seasonal pattern of increased paediatric hospital admission corresponds to the seasonal pattern of elevated river water level, and this relationship pattern is modified by the change in temperature. Young children are more sensitive to the annual river flood pulse and climate factors than the schoolaged children, and the most concerned disease group is respiratory infection. These results indicate important implications of the projected local changes in climate on human health impacts in Mekong Delta region (MDR), which has been considered to be one of the most vulnerable areas to climate change in Southeast Asia. This work may make a significant contribution to local health prevention and hospital preparedness for children's health in Can Tho city. However, for more comprehensive solutions of disease prevention, the further studies should be conducted to better understanding the interaction between flooding effects and some potentially modified factors, including: genders, age-specific $(0-2,3-5$, and $>=5$ which corresponding to home-care, kindergarten-care, and school-age children), causespecific for individual disease, socioeconomic status, infrastructural factors, and identifications of the most cost-effective mitigation and adaptation from children's health perspective. 


\section{Acknowledgment}

This work was supported by Commonwealth Scientific and Industrial Research Organisation (CSIRO). We thank colleagues at HEMA, Ministry of Health and Can Tho Health Agencies for permission and support to our data collection.

\section{Competing Financial Interest}

The authors declare they have no actual or potential competing financial interests 


\section{References}

Abaya SW, Mandere N \& Ewald G 2009. Floods and health in Gambella region. Ethiopia: a qualitative assessment of the strengths and weakness of coping mechanisms. Glob Health Action, 2.

Ahern M, Kovats R, Wilkinson P, Few R \& Matthies F 2005. Global health impacts of floods: epidemiologiuc evidence. Epidemiological Reviews, 27, 36-46.

Alderman K, Turner LR \& Tong S 2012. Floods and human health: A systematic review. Environment International, 47, 37-47.

Aramini J, Mclean M, Wilson J, Holt J, Copes R, Allen B, et al. 2000. Drinking water quality and health care utilization for gastrointestinal illness in Freater Vancouver. Canada Communicable Disease Report, 26, 211-214.

Bates BC, Kundzewicz ZW, Wu S \& Palutikof JP 2008. Climate change and water. Technical Paper VI of the Intergovernmental Panel on Climate Chnage IPCC Secreteriat, Geneva.

Berry H, Kelly B, Hanigan I, Coates J, Mcmichael A, Welsh J, et al. 2008. Rural metal health impacts of climate change Garnaut Climate Change Review. The Australian National University College of Medicine and Health Sciences.

Birkmann J, Garchagen M, Vo VT \& Nguyen TB 2010. Vulnerability Profiles with Respect to Present and Future Water Related Hazards in the Vietnamese Mekong Delta Providing the information-base for successful coping and adaptation within the framework of integrated water resources management.

Bush KF, O'neill MS, Li S, Mukherjee B, Hu H, Shosh S, et al. 2014. Association between Extreme Precipitation and Gastrointestinal-Related HOspital Admission in Chennai, India. Environ Health Perspect, 122, 249-254.

Caroll B, Balogh R, Morbey H \& Araoz G 2010. Health and social impact of a flood disaster: responding to needs and implications for practice. Disasters, 34, 1045-1063.

Ccdr 2000. Waterborne Outbreak of Gastroenteritis Associated with a Contaminated Municipal Water Supply, Walkerton, Ontario, May-June 2000. Can. Commun. Dis. Rep., 26, 170-173.

Cfsc [Committee for Flood and Storm Control SROV 2004. National Report on Disaster Reduction in Vietnam. For the World Conference on Disaster Reduction, KobeHyogo, Japan, 18-22 Januray 2005.

Checkly W, Epstein LD, Gilman RH, Figueroa D, Cama RI \& Patz JA 2000. Effects of El nino and ambient temperature on hospital admission for diarrhoeal diseases in Peruvian children. Lancet, 355, 442-450.

Chen MJ, Lin CY, Wu YT, Wu PC, Lung SC \& Su HJ 2012. Effects of extreme precipitation to the distribution of infectious disease in Taiwas, 1994-2008. 7:e34651; doi: 10.1289/ehp. 119-a394. Plos One.

Chief Medical Officer 2001. Getting ahead of the curve. A Strategy for Combating Infectious Diseases (Including Other Aspects of Health Protection). London: Department of Health.

Cowel RR 1996. Global climate change and infectious disease: the cholera paradigm. Science 274, 2025-2031.

Curriero FC, Patz J, Rose J \& Lele S 2001. The association between extreme precipitation and waterborne disease outbreaks in the United States, 1948-1994. Am J Public Health, 91, 1194-1199.

Delgado KM, Apel H \& Merz B 2010. Flood trends and variability in the Mekong river. Hydrol. Earth Syst. Sci., 14, 407-418. 
Diaz J 2004. The public health impact of hurricanes and major flooding. J La State Med Soc, 156, 145-150.

Du W, Fitzgerald G, Clark M \& Hou X 2010. Health impacts of floods. Prehosp Disaster Med, 25, 265-272.

Eastham J, Mpelasoka F, Mainuddin M, Ticehurst C, Dyce P, Hodgson G, et al. 2008. Mekong River Basin Water REsources Assessment: Impacts of Climate Change. CSIRO: Water for a Healthy Country National Research Flagship.

Euripidou E \& Murray V 2004. Public health impact of flood and chemical contamination. $J$ Public Health, 26, 376-383.

Fleury M, Charron DF, Holt JD, Allen OB \& Maarouf AR 2006. A time series analysis of the relationship of ambient temperature and common bacterial enteric infectious in two Canadian provinces. Int J Biometeorol, 50, 385-391.

Fox M, Chari R, Resnick B \& Burke T 2009. Potential for chemical mixture exposure and health risks in New Orleans post-Hurricane Katrina. Human and Ecol Risk Assess, 15, 831-845.

Goudet S, Faiz S, Bogin B \& Griffiths P 2011. Pregnant women's and community health workers' perceptions of root causes of malnutrition among infants and young children in the slums of Dhaka, Bangladesh. Am J Public Health, 101, 1225-1233.

Harper SL, Edge VL, Schuster-Wallace CJ, Berke O \& Mcewen SA 2011. Weather, Water Quality and Infectious Gastrointestinal Illness in Two Inuit Communities in Nunatsiavut, Canada: Potential Implications for Climate Change. EcoHealth, 8, 93108.

Hashizume M, Amstrong B, Hajat S, Watgatsuma Y, Faruque AS, Hayashi T, et al. 2007a. Association between climate variability and hospital visits for non-cholera diarrhoea in Bangladesh: effects and vulnerable groups. International Journal of Epidemiology 36, 1030-1037.

Hashizume M, Armstrong B, Wagatsuma Y, Faruque ASG, Hayashi T \& Sack DA 2007b. Rotavirus infections and climate variability in Dhaka, Bangladesh: a time-series analysis. Epidemiol. Infect., 136, 1281-1289.

Hungerford JM 2001. Seafood toxins. In Guide to foodborne pathogens ed. Labbe, R.G. and Garcia S. pp. 267-283. New York: John Wiley and Sons.

Hunter Health 2003. North Lake Maccquarie Blood Lead Monitoring Service. Summary of Results (July 2001-June2002). Public Information Paper. Newcastle, Australia: Hunter Health, February, 1-4.

Hunter PR 1998. Cyanobacterial toxins and human health. Journal of Applied Bacteriology, 84(suppl), 35S-40S.

Huyen NC 2012. Atlas of Vietnamese City: Hanoi - Ho Chi Minh - Hai Phong - Da Nang Can Tho, Hanoi, Vietnam Publishing House of Natural Resources, Environment and Cargraphy.

Islam MS, Draser BS \& Bradley DJ 1990. Long-ter, persistence of toxigenic Vibro cholera $\mathrm{O} 1$ in the mucilagionous sheath of a blue-green alga, Anabaena variabilis. Journal of Tropical Medicine and Hygiene, 93, 133-139.

Jacobs JW 1995. Adjusting to climate change in the Lower Mekong. Global Environmental Change, 6, 7-22.

Jonkman S, Maaskant B, Boyd E \& Levitant M 2009. Loss of life cuased by the floodong of New Orleans after Huricane Katrina: analysis of the relationship between flood chracteristics and mortality. Risk Anal., 29, 676-698.

Morris J 1999. Pfiesteria, "the cell from hell", and other toxic nightmares. Clinical Infection Disease, 28, 1191-1196. 
Namouva EN, Jagai JS, Matyas B, Demaria J, Macneill IB \& Griffiths JK 2007. Seasonality in six enterically transmitted diseases and ambient temperature. Epidemiol. Infect., 135, 281-292.

Neumann L, Nguyen M, Moglia M, Cook S \& Lipkin F 2013. Urban Water Systems in Can Tho, Vietnam: Understanding the current context for climate change adaptation. From: www.csiro.au.

Nichols G, Lane C, Asgari N, Verlander NQ \& Charlett A 2009. Rainfall and outbreaks of drinking water related disease and in England and Wales. $J$ Water Health, 7, 1-8.

Nino CD \& Lundberg M 2005. Treading water: the long-term impact of the 1998 flood on nutrition in Bangladesh. Econ Hum Biol, 3, 67-96.

Pradhan E, Katz J, Leclerq S, Khatry S \& Shrestha S 2007. Risk of flood-related mortality in Nepal. Disasters, 31, 57-70.

Prudhomme C, Jakob D \& Svensson C 2003. Uncertainty and climate change impact on the flood regime of small UK catchments. Journal of Hydrology, 277, 1-23.

Reacher M, Mckenzie K, Lane C, Nichols T, Kedge I, Iversen A, et al. 2004. Health impacts of floodings in Lewes: a comparison of reported gastrointestinal and other illness and mental health in flooded and non-flooded househols. Commun Dis Public Health, 7, 39-46.

Rose JB, Daeschner S, Easterling DR, Curriero FC, Lele S \& Patz JA 2000. Climate and waterborne disease outbreaks. J Am Water Works Assoc, 92, 77-87.

Schuster CJ, Ellis AA, Robertson WJ, Charron DE, Aramini JJ, Marshall BJ, et al. 2005. Infectious disease outbreaks related to drinking water in Canada, 1974-2001. Canadian Journal of Public Health, 96, 254-258.

Schwartz B, Harris J, Khan A, Larocque R, Sack D \& Malek M 2006. Diarrheal epidemics in Dhaka, Bangladesh, during three consecutive floods: 1988, 1998, and 2004. Am J Trop Med Hyg, 74, 1067-1073.

Schwartz J, Levin R \& Hodge K 1997. Drinking water tubidity and pediatric hospital use for gastrointestinal illness in Philadenphia. Epidemiology 8, 615-620.

Sidley P 2008. Floods in Mozambique results in cholera and displacement. BMI, 336, 471.

Singh RBK, Hales S, Wet ND, Raj R, Hearnden M \& Weinstein P 2001. The influence of climate variation and change on diarrhoeal disease in the Pacific Islands. Envi Health Persp, 109, 155-159.

Sullivent E, West C, Noe R, Thomas K, Wallace L \& Leeb R 2006. Nonfatal injuries following Hurricane Katrina - New Orleans, Lousiana. J Safety Res, 37, 213-217.

Tapsell SM, Penning-Rowsell EC, Tunstall SM \& Wilson TL 2002. Vunerability to flooding: health and social dimensions. Philosophical Transaction of The Royal Society, 360, 1511-1525.

Thomas MK, Charron DF, Waltner-Toews D, Schuster C, Maarouf AR \& Holt JD 2006. A role of high impact weather events in waterborne disease outbreaks in Canada, 19752001. International Journal of ENvironmental Health Research, 16, 167-180.

Vastila K, Kummu M, Sangmanee C \& Chinvanno S 2010. Modelling climate change impacts on the flood pulse in the lower Mekong Floodplains. Journal of water and climate change, $167-86$.

Vollaard A, Ali S, Asten HV, Widjaja S, Visser L, Surjadi C, et al. 2004. Risk factors for typhoid and paratyphoid fever in Jakarta, Indonesia. JAMA, 291, 2607-2015.

World Health Organization 2011. Flooding and Communicable Diseases Fact Sheet. Retrieved January 2014, from http://www.who.int/hac/techguidance/ems/floods/en/index.html.

Yeo S \& Blong R 2010. Fiji's wrost natural disaster: the 1931 hurricane and flood. . Disasters, 34, 657-683. 
Yusuf AA \& Francisco H 2009. Climate Change Vulnerability Mapping for Southeast Asia. In: ASIA, E. A. E. P. F. S. (ed.). Singapore. 
Table 1. Daily average river water level (RWL) and meteorological conditions categorized by year and by season in Can Tho city $2008-2011$ [minimum, maximum, mean, and (95\% Confidence Interval)] and number of extreme events of RWL.

\begin{tabular}{|c|c|c|c|c|}
\hline \multirow[t]{2}{*}{ Variable } & \multicolumn{2}{|c|}{ River water level } & \multirow{2}{*}{$\begin{array}{c}\text { Temperature } \\
\left({ }^{\circ} \mathrm{C}\right)\end{array}$} & \multirow{2}{*}{$\begin{array}{c}\text { Humidity } \\
(\%)\end{array}$} \\
\hline & $\begin{array}{l}\text { Level } \\
(\mathrm{cm})\end{array}$ & $\begin{array}{l}\text { Extreme } \\
\text { events (n) }\end{array}$ & & \\
\hline \multicolumn{5}{|l|}{ By year } \\
\hline 2008 & $65 ; 200 ; 125(122-128)$ & 37 & $22.2 ; 29.7 ; 26.8$ (26.7-27.0) & 66; 97; 83.1 (82.5-83.7) \\
\hline 2009 & $45 ; 193 ; 121(118-124)$ & 35 & $21.5 ; 29.9 ; 27.2(27.0-27.4)$ & 67; 96; 82.4 (81.8-82.9) \\
\hline 2010 & $40 ; 194 ; 125$ (119-125) & 28 & $22.8 ; 31.4 ; 27.6$ (27.4-27.8) & 65; 97; 81.7 (81.1-82.5) \\
\hline 2011 & 67; 215; 132 (128-135) & 49 & $23.5 ; 30.2 ; 27.2(27.0-27.3)$ & 66; 96; 81 (80.4-81.5) \\
\hline \multicolumn{5}{|l|}{ By season } \\
\hline Dry (December-April) & $40 ; 184 ; 120$ (119.4-122.4) & 17 & 21.5; 30.2; 27.3 (27.2-27.4) & 65; 96; 82 (81.8-82.4) \\
\hline Wet (May-November) & $65 ; 215 ; 130$ (126.4-130.7) & 132 & $23.9 ; 31.4 ; 27.4$ (27.3-27.5) & $67 ; 97 ; 84.5$ (84.1-84.8) \\
\hline Entire period (2008-2011) & $40 ; 215 ; 125(123-126)$ & 149 & 21.5; 31.4; 27.2 (27.1-27.3) & 65; 97; 82 (81.7-82.3) \\
\hline
\end{tabular}

The $90^{\text {th }}$ percentile of the RWL for the entire study period $(166 \mathrm{~cm})$ was used as the cut-off point to define extreme RWL. 
Table 2. Daily paediatric hospital admission (PHA, total counts \& \%) by year, season, age, and cause from Can Tho Paediatric Hospital, $2008-2011$.

\begin{tabular}{|c|c|c|c|c|c|c|}
\hline \multirow[t]{2}{*}{ Variable } & \multicolumn{2}{|c|}{ Age } & \multicolumn{4}{|c|}{ Disease group } \\
\hline & $<=5$ & $5-15$ & All cause & $\begin{array}{c}\text { Communicable } \\
\text { infection }\end{array}$ & $\begin{array}{l}\text { Respiratory } \\
\text { infection }\end{array}$ & Others \\
\hline \multicolumn{7}{|l|}{ By year } \\
\hline 2008 & $7,890(23)$ & $1,969(20)$ & $9,859(22)$ & $3,744(21)$ & $2,345(22)$ & $3,770(24)$ \\
\hline 2009 & $8,593(25)$ & 2,940 (29) & $11,533(26)$ & $4,636(26)$ & $2,760(26)$ & $4,137(26)$ \\
\hline 2010 & $8,920(26)$ & 2,962 (30) & $11,882(27)$ & $5,176(29)$ & 3,057 (28) & 3,649 (23) \\
\hline 2011 & 8,957 (26) & $2,131(21)$ & $11,088(25)$ & $4,160(23)$ & $2,463(23)$ & $4,465(27)$ \\
\hline \multicolumn{7}{|l|}{ By season } \\
\hline Dry (December-April) & 12,694 (37) & 3,421 (34) & $12,741(27)$ & $4,805(27)$ & 2,934 (28) & 5,002 (31\%) \\
\hline Wet (May-November) & 21,666 (63) & 6,581 (66) & $31,621(73)$ & $12,911(73)$ & $7,691(72)$ & $11,019(69 \%)$ \\
\hline Entire period (2008-2011) & $34,360(77.5)$ & $10,002(22.5)$ & 44,362 & $17,716(40)$ & $10,625(24)$ & 16,021 (36) \\
\hline
\end{tabular}

180 admissions, which were external causes and missing values, were excluded from the analysis. 
Table 3. Cumulative risk ratio effects of paediatric hospital admissions associated with extreme river water level (RWL) by disease group and age category

\begin{tabular}{|c|c|c|c|}
\hline Category & $\begin{array}{c}\text { Cumulative Risk } \\
\text { Ratio } \\
\end{array}$ & $95 \% \mathrm{CI}$ & p-value \\
\hline \multicolumn{4}{|l|}{ Age groups } \\
\hline All ages & 1.26 & $1.20-1.38$ & $<0.01$ \\
\hline$<=5$ years & 1.27 & $1.23-1.30$ & $<0.01$ \\
\hline$>5$ years & 1.15 & $1.07-1.20$ & $<0.01$ \\
\hline \multicolumn{4}{|l|}{ Disease groups } \\
\hline All causes & 1.24 & $1.21-1.27$ & $<0.01$ \\
\hline Communicable infection & 1.18 & $1.13-1.22$ & $<0.01$ \\
\hline Respiratory infection & 1.66 & $1.57-1.74$ & $<0.01$ \\
\hline Others & 1.06 & $1.01-1.1$ & 0.01 \\
\hline
\end{tabular}

The cumulative RR was computed from the multivariate Poisson distributed lag model adjusted for daily average temperature, relative humidity, day of week, seasonal and longterm trend, and a quadratic distributed lag function was added into the model. 
Abaya SW, Mandere N \& Ewald G 2009. Floods and health in Gambella region. Ethiopia: a qualitative assessment of the strengths and weakness of coping mechanisms. Glob Health Action, 2.

Adger W 2006. Vulnerability. Glob Environ Chang, 16, 268-281.

Ahern M, Kovats R, Wilkinson P, Few R \& Matthies F 2005. Global health impacts of floods: epidemiologiuc evidence. Epidemiological Reviews, 27, 36-46.

Alderman K, Turner LR \& Tong S 2012. Floods and human health: A systematic review. Environment International, 47, 37-47.

Aramini J, Mclean M, Wilson J, Holt J, Copes R, Allen B, et al. 2000. Drinking water quality and health care utilization for gastrointestinal illness in Freater Vancouver. Canada Communicable Disease Report, 26, 211-214.

Bates BC, Kundzewicz ZW, Wu S \& Palutikof JP 2008. Climate change and water. Technical Paper VI of the Intergovernmental Panel on Climate Chnage IPCC Secreteriat, Geneva.

Berry H, Kelly B, Hanigan I, Coates J, Mcmichael A, Welsh J, et al. 2008. Rural metal health impacts of climate change Garnaut Climate Change Review. The Australian National University College of Medicine and Health Sciences.

Birkmann J, Garchagen M, Vo VT \& Nguyen TB 2010. Vulnerability Profiles with Respect to Present and Future Water Related Hazards in the Vietnamese Mekong Delta - Providing the information-base for successful coping and adaptation within the framework of integrated water resources management.

Bunyavanich S, Landrigan CP, Mcmichael AJ \& Epstein PR 2003. The IMpact of Climate Change on Children Health. Ambulatory Pediatrics, 3, 44-51.

Bush KF, O'neill MS, Li S, Mukherjee B, Hu H, Shosh S, et al. 2014. Association between Extreme Precipitation and Gastrointestinal-Related HOspital Admission in Chennai, India. Environ Health Perspect, 122, 249-254.

Caroll B, Balogh R, Morbey H \& Araoz G 2010. Health and social impact of a flood disaster: responding to needs and implications for practice. Disasters, 34, 1045-1063.

Ccdr 2000. Waterborne Outbreak of Gastroenteritis Associated with a Contaminated Municipal Water Supply, Walkerton, Ontario, May-June 2000. Can. Commun. Dis. Rep., 26, 170-173.

Cfsc [Committee for Flood and Storm Control SROV 2004. National Report on Disaster Reduction in Vietnam. For the World Conference on Disaster Reduction, Kobe-Hyogo, Japan, 18-22 Januray 2005.

Checkly W, Epstein LD, Gilman RH, Figueroa D, Cama RI \& Patz JA 2000. Effects of El nino and ambient temperature on hospital admission for diarrhoeal diseases in Peruvian children. Lancet, 355, 442-450.

Chief Medical Officer 2001. Getting ahead of the curve. A Strategy for Combating Infectious Diseases (Including Other Aspects of Health Protection). London: Department of Health.

Corner RJ, Dewan AM \& M. Hashizume M, 13. 2013. Modelling typhoid risk in Dhaka Metropolitan Area of Bangladesh: the role of socio-economic and environmental factors. International journal of health geographics, 12, 1-15.

Curriero FC, Patz J, Rose J \& Lele S 2001. The association between extreme precipitation and waterborne disease outbreaks in the United States, 1948-1994. Am J Public Health, 91, 11941199.

Delgado KM, Apel H \& Merz B 2010. Flood trends and variability in the Mekong river. Hydrol. Earth Syst. Sci., 14, 407-418.

Dewan A 2013. Floods in a megacity: geospatial techniques in assessing hazards, risk and vulnerability, Springer Dordrecht Heidelberg

Dewan AM, Corner R, Hashizume M \& Ongee ET 2013. Typhoid Fever and Its Association with Environmental Factors in Dhaka Metropolitant Area of Bangladesh: A Spatial and Time-Series Approach. Plos Neglected Tropical Diseases, 7, e1998. 
Dewan AM \& Yamaguchi Y 2008. Effect of land cover changes on flooding: example from Greater Dhaka of Bangladesh. International Journal of Geoinformatics, 4, 11-19.

Diaz J 2004. The public health impact of hurricanes and major flooding. J La State Med Soc, 156, 145150.

Dominici F, Samet JM \& Zeger SL 2000. Combining evidence on air pollution and daily mortality from the 20 largest US cities: a hierchical modelling strategy. J R Stat Soc a Sta, 163, 263-284.

Du W, Fitzgerald G, Clark M \& Hou X 2010. Health impacts of floods. Prehosp Disaster Med, 25, 265272.

Eastham J, Mpelasoka F, Mainuddin M, Ticehurst C, Dyce P, Hodgson G, et al. 2008. Mekong River Basin Water REsources Assessment: Impacts of Climate Change. CSIRO: Water for a Healthy Country National Research Flagship.

Euripidou E \& Murray V 2004. Public health impact of flood and chemical contamination. J Public Health, 26, 376-383.

Few R, Lake I, Hunter PR, Pham GT \& Vu TT 2009. Seasonal hazards and health risks in lower-income countries: field testing a multi-disciplinary approach. Environmental Health, 8.

Fleury M, Charron DF, Holt JD, Allen OB \& Maarouf AR 2006. A time series analysis of the relationship of ambient temperature and common bacterial enteric infectious in two Canadian provinces. Int J Biometeorol, 50, 385-391.

Fox M, Chari R, Resnick B \& Burke T 2009. Potential for chemical mixture exposure and health risks in New Orleans post-Hurricane Katrina. Human and Ecol Risk Assess, 15, 831-845.

Goudet S, Faiz S, Bogin B \& Griffiths P 2011. Pregnant women's and community health workers' perceptions of root causes of malnutrition among infants and young children in the slums of Dhaka, Bangladesh. Am J Public Health, 101, 1225-1233.

Harper SL, Edge VL, Schuster-Wallace CJ, Berke O \& Mcewen SA 2011. Weather, Water Quality and Infectious Gastrointestinal Illness in Two Inuit Communities in Nunatsiavut, Canada: Potential Implications for Climate Change. EcoHealth, 8, 93-108.

Hashizume M, Amstrong B, Hajat S, Watgatsuma Y, Faruque AS, Hayashi T, et al. 2007a. Association between climate variability and hospital visits for non-cholera diarrhoea in Bangladesh: effects and vulnerable groups. International Journal of Epidemiology 36, 1030-1037.

Hashizume M, Armstrong B, Wagatsuma Y, Faruque ASG, Hayashi T \& Sack DA 2007b. Rotavirus infections and climate variability in Dhaka, Bangladesh: a time-series analysis. Epidemiol. Infect., 136, 1281-1289.

Hashizume M, Dewan AM, Sunahara T, Rahman MZ \& Yamamoto T 2012. Hydroclimatological variability and dengue transmission in Dhaka, Bangladesh: a time-series study. BMC Infect Dis, 12, 1-9.

Hungerford JM 2001. Seafood toxins. In Guide to foodborne pathogens ed. Labbe, R.G. and Garcia S. pp. 267-283. New York: John Wiley and Sons.

Hunter Health 2003. North Lake Maccquarie Blood Lead Monitoring Service. Summary of Results (July 2001-June2002). Public Information Paper. Newcastle, Australia: Hunter Health, February, 1-4.

Hunter PR 1998. Cyanobacterial toxins and human health. Journal of Applied Bacteriology, 84(suppl), 35S-40S.

Huyen NC 2012. Atlas of Vietnamese City: Hanoi - Ho Chi Minh - Hai Phong - Da Nang - Can Tho, Hanoi, Vietnam Publishing House of Natural Resources, Environment and Cargraphy.

Jonkman S, Maaskant B, Boyd E \& Levitant M 2009. Loss of life cuased by the floodong of New Orleans after Huricane Katrina: analysis of the relationship between flood chracteristics and mortality. Risk Anal., 29, 676-698.

Kelly-Hope LA, Alonso WJ, Vu TD, Do GC, Dang AD, Lee H, et al. 2008. Temporal Trends and Climatic Factors Associated with Bacterial Enteric Diseases in Vietnam, 1991-2001. Envi Health Persp, 116, 7-12. 
Kien TM, Tran TTH, Cuong HD \& Shaw R 2010. IDENTIFYING LINKAGES BETWEEN RATES AND DISTRIBUTIONS OF MALARIA, WATER-BORN DISEASES AND INFLUENZA WITH CLIMATE VARIABILITY AND CLIMATE CHANGE IN VIETNAM. In: SHAW, R., PULHIN, J. M. \& PEREIRA, J. J. (eds.) Climate Change Adaptation and Disaster Risk Reduction: An Asian Perspective.

Morris J 1999. Pfiesteria, "the cell from hell", and other toxic nightmares. Clinical Infection Disease, 28, 1191-1196.

Namouva EN, Jagai JS, Matyas B, Demaria J, Macneill IB \& Griffiths JK 2007. Seasonality in six enterically transmitted diseases and ambient temperature. Epidemiol. Infect., 135, 281-292.

Neumann L, Nguyen M, Moglia M, Cook S \& Lipkin F 2013. Urban Water Systems in Can Tho, Vietnam: Understanding the current context for climate change adaptation. From: www.csiro.au.

Nichols G, Lane C, Asgari N, Verlander NQ \& Charlett A 2009. Rainfall and outbreaks of drinking water related disease and in England and Wales. J Water Health, 7, 1-8.

Nino CD \& Lundberg M 2005. Treading water: the long-term impact of the 1998 flood on nutrition in Bangladesh. Econ Hum Biol, 3, 67-96.

Nirupama N \& Simonovic SP 2007. Increase of flood risk due to urbanization: a Canadian example. Natural Hazards, 40, 25-41.

Pradhan E, Katz J, Leclerq S, Khatry S \& Shrestha S 2007. Risk of flood-related mortality in Nepal. Disasters, 31, 57-70.

Prudhomme C, Jakob D \& Svensson C 2003. Uncertainty and climate change impact on the flood regime of small UK catchments. Journal of Hydrology, 277, 1-23.

Reacher M, Mckenzie K, Lane C, Nichols T, Kedge I, Iversen A, et al. 2004. Health impacts of floodings in Lewes: a comparison of reported gastrointestinal and other illness and mental health in flooded and non-flooded househols. Commun Dis Public Health, 7, 39-46.

Rose JB, Daeschner S, Easterling DR, Curriero FC, Lele S \& Patz JA 2000. Climate and waterborne disease outbreaks. J Am Water Works Assoc, 92, 77-87.

Royston P \& Sauerbrei W 2007. Multivariable modeling with cubic regression splines: A principled approach. The Stata Journal, 7, 45-70.

Schuster CJ, Ellis AA, Robertson WJ, Charron DE, Aramini JJ, Marshall BJ, et al. 2005. Infectious disease outbreaks related to drinking water in Canada, 1974-2001. Canadian Journal of Public Health, 96, 254-258.

Schwartz B, Harris J, Khan A, Larocque R, Sack D \& Malek M 2006. Diarrheal epidemics in Dhaka, Bangladesh, during three consecutive floods: 1988, 1998, and 2004. Am J Trop Med Hyg, 74, 1067-1073.

Schwartz J, Levin R \& Hodge K 1997. Drinking water tubidity and pediatric hospital use for gastrointestinal illness in Philadenphia. Epidemiology 8, 615-620.

Sidley P 2008. Floods in Mozambique results in cholera and displacement. BMI, 336, 471.

Singh RBK, Hales S, Wet ND, Raj R, Hearnden M \& Weinstein P 2001. The influence of climate variation and change on diarrhoeal disease in the Pacific Islands. Envi Health Persp, 109, 155159.

Sullivent E, West C, Noe R, Thomas K, Wallace L \& Leeb R 2006. Nonfatal injuries following Hurricane Katrina - New Orleans, Lousiana. J Safety Res, 37, 213-217.

Thomas MK, Charron DF, Waltner-Toews D, Schuster C, Maarouf AR \& Holt JD 2006. A role of high impact weather events in waterborne disease outbreaks in Canada, 1975-2001. International Journal of ENvironmental Health Research, 16, 167-180.

Tol RSJ 2008. Why worry about climate change? A research agenda. Environ Value 17, 437-470.

Vastila K, Kummu M, Sangmanee C \& Chinvanno S 2010. Modelling climate change impacts on the flood pulse in the lower Mekong Floodplains. Journal of water and climate change, 167-86.

Vollaard A, Ali S, Asten HV, Widjaja S, Visser L, Surjadi C, et al. 2004. Risk factors for typhoid and paratyphoid fever in Jakarta, Indonesia. JAMA, 291, 2607-2015. 
World Health Organization 2011. Flooding and Communicable Diseases Fact Sheet. Retrieved January 2014, from http://www.who.int/hac/techguidance/ems/floods/en/index.html.

Yeo S \& Blong R 2010. Fiji's wrost natural disaster: the 1931 hurricane and flood. . Disasters, 34, 657683.

Yusuf AA \& Francisco H 2009. Climate Change Vulnerability Mapping for Southeast Asia. In: ASIA, E. A. E. P. F. S. (ed.). Singapore. 


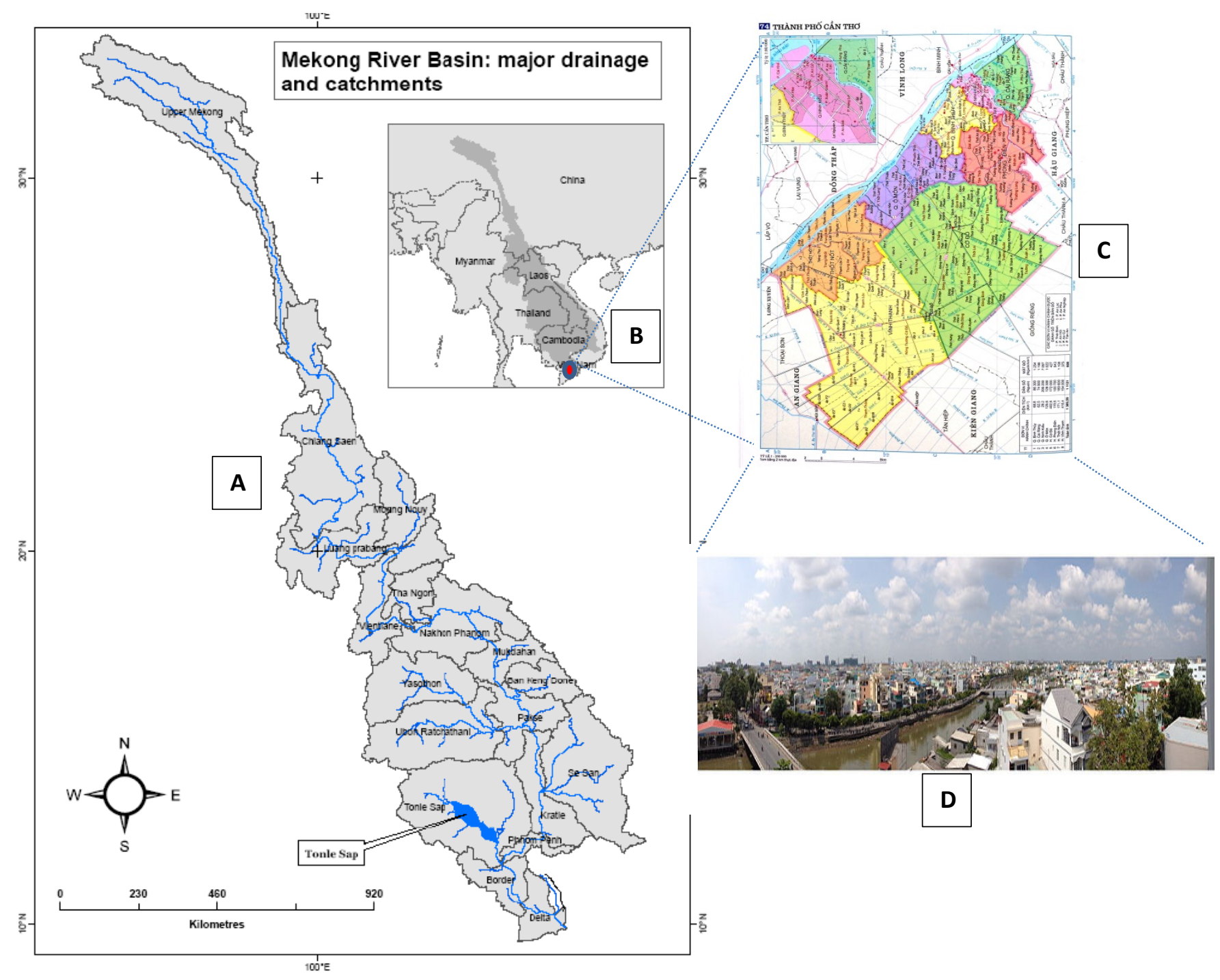

Figure 1. (A) Mekong Delta Basin; (B) Vietnam; (C) Can Tho City; (D) Can Tho panorama

(Source: Estham, 2008; Google maps; and Wikipedia) 


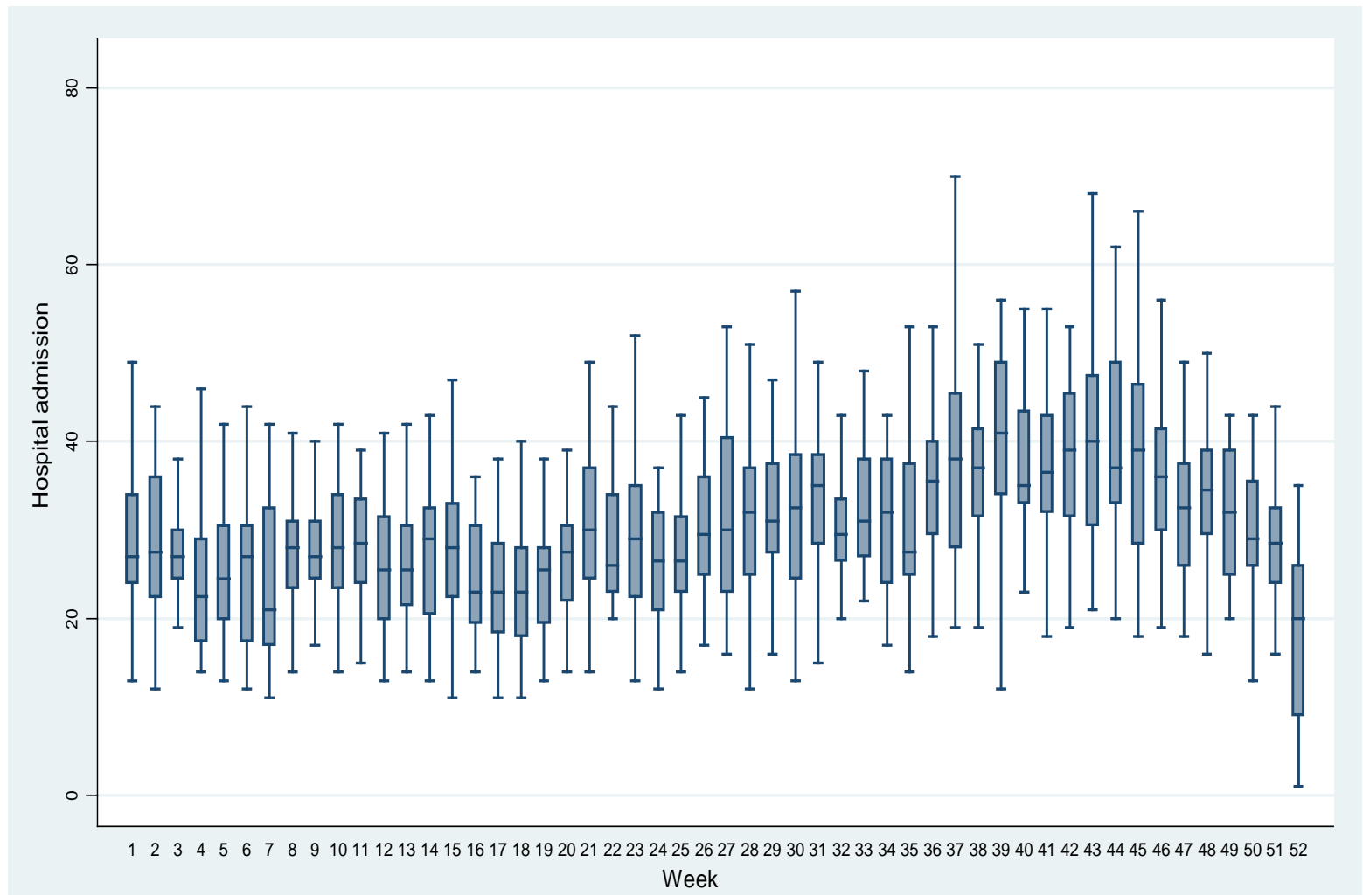

Figure 2. Weekly paediatric hospital admissions (minimum, $25^{\text {th }}, 50^{\text {th }}, 75^{\text {th }}$, maximum) in a year 

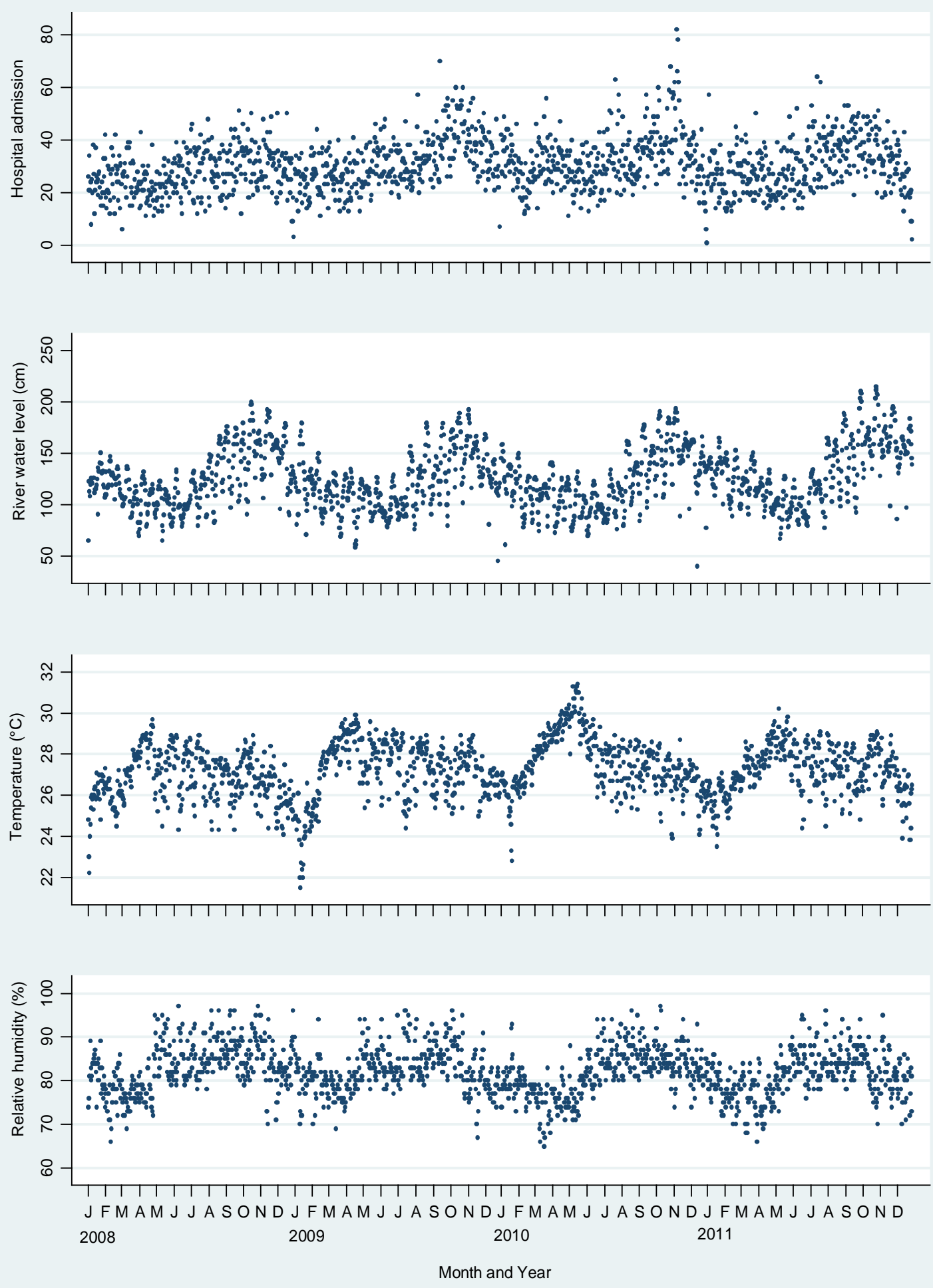

Figure 3. Daily time series between 2008 to 2011, for paediatric hospital admissions, river water level, average temperature and relative humidity in Can Tho city, Vietnam. 


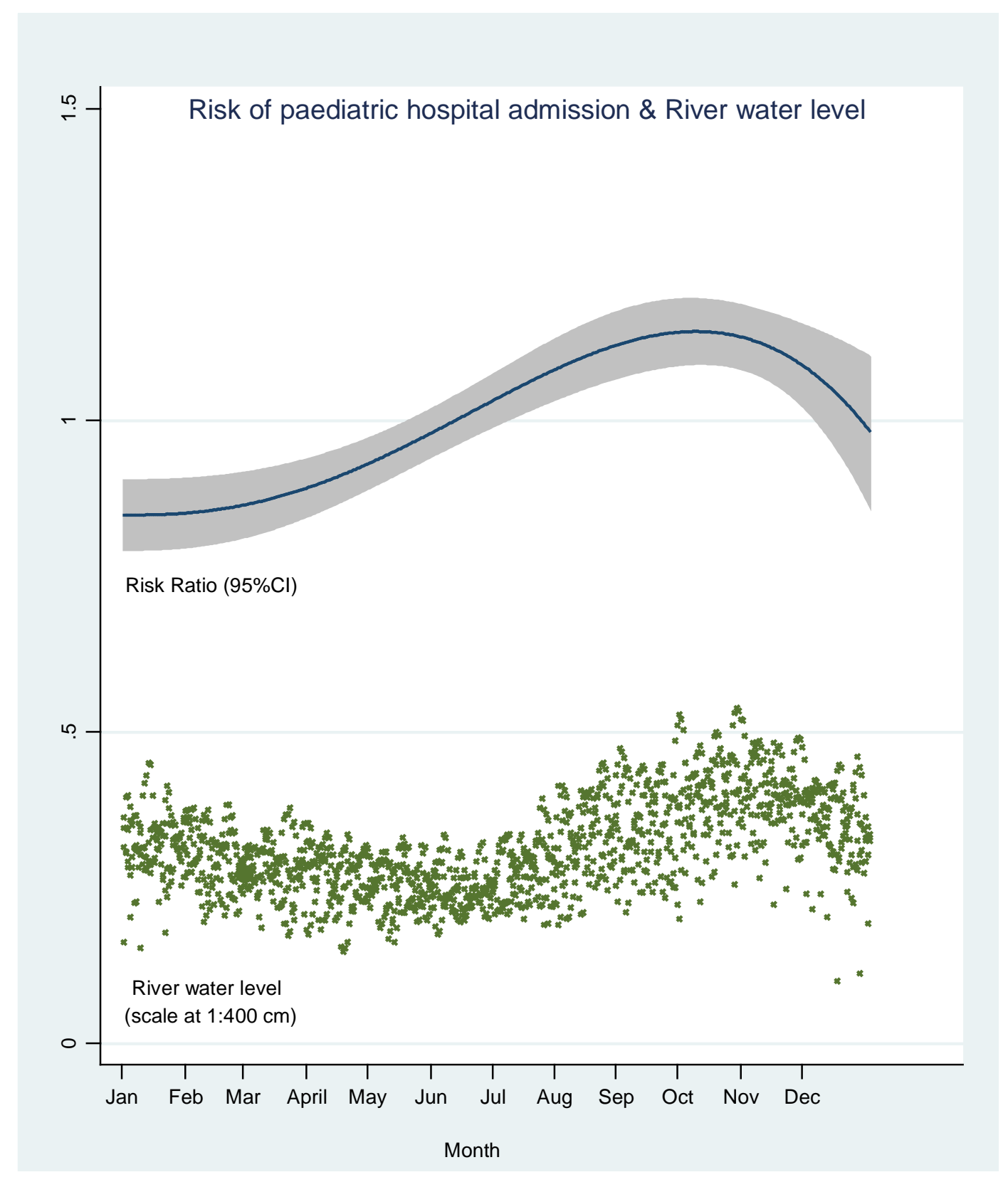

Figure 4. Seasonal pattern of risk ratio of paediatric hospital admission and river water level. 


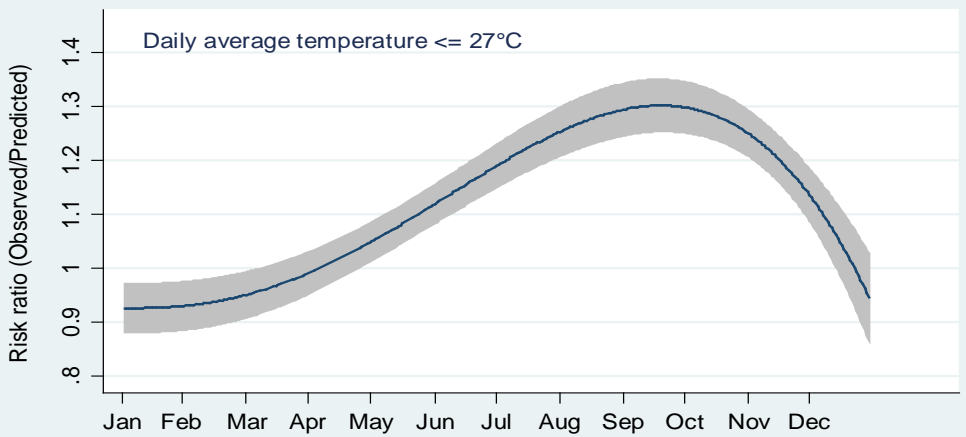

Jan Feb Mar Apr May Jun Jul Aug Sep Oct Nov Dec

\begin{tabular}{|ll|}
\hline \multicolumn{1}{|c|}{ Month } & \\
\hline $95 \% \mathrm{Cl}$ & predicted $\mathrm{rr}$ \\
\hline
\end{tabular}

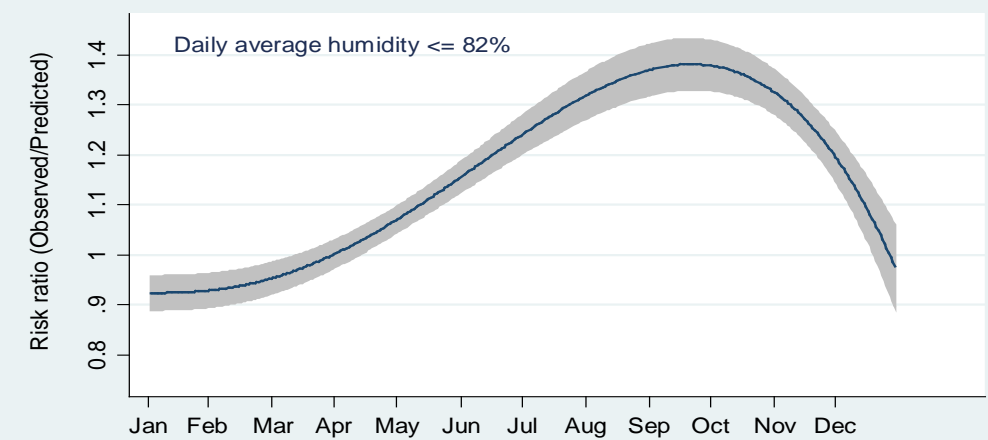

Jan Feb Mar Apr May Jun Jul Aug Sep Oct Nov Dec

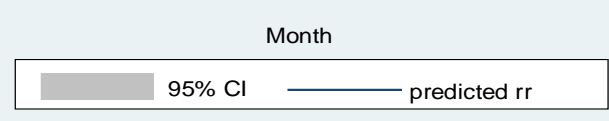

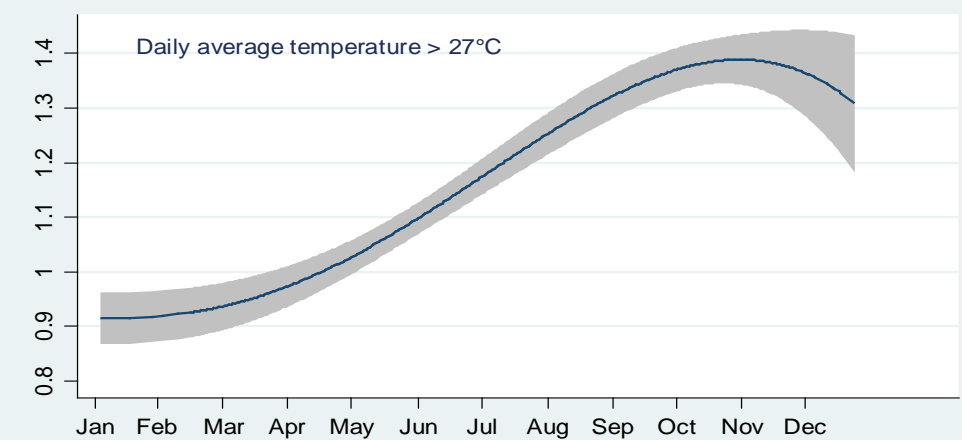
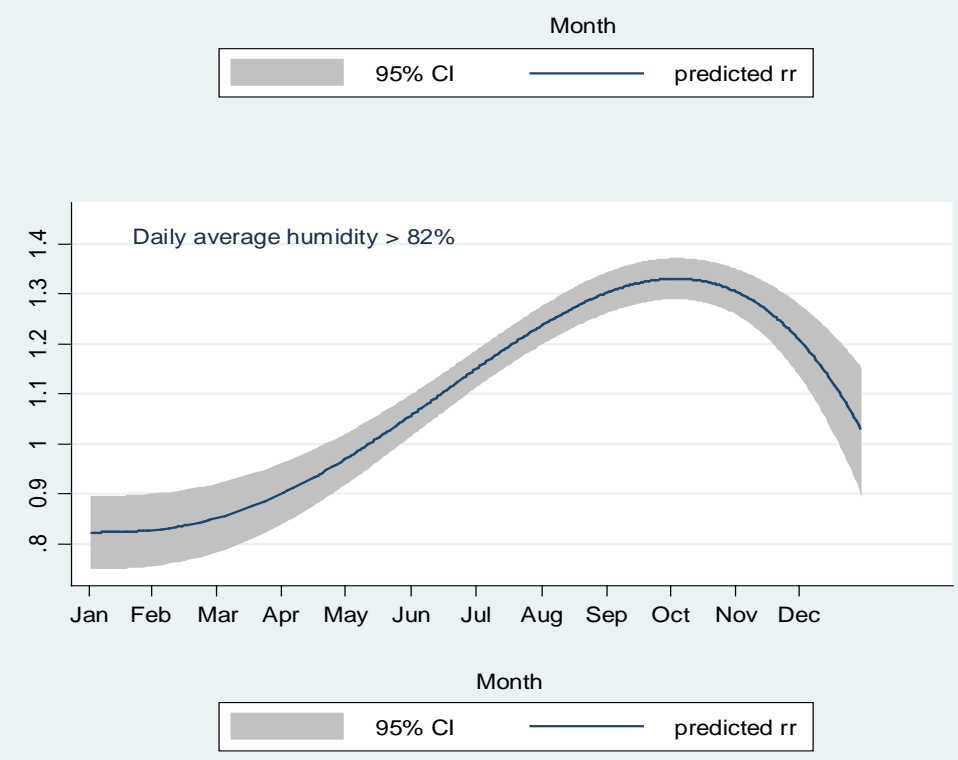

Figure 5. Seasonal pattern of risk ratio of paediatric hospital admission by temperature and humidity. 